\title{
Seasonal incidence and efficacy of botanical insecticides against Painted bug, Bagrada hilaris (Burmeister) (Hemiptera: Pentatomidae) in Indian mustard (Brassica juncea genotype RH 725)
}

\author{
Hemant Kumar* \\ Department of Zoology, Singhania University, Pacheri Bari, Jhunjhunu-333515 (Rajasthan) \\ India \\ Sumer Singh \\ Department of Zoology, Singhania University, Pacheri Bari, Jhunjhunu-333515 (Rajasthan), \\ India \\ Amit Yadav \\ Department of Entomology, Raffles University, Neemrana, Alwar-301705 (Rajasthan), India \\ Mahesh Kumar \\ Department of Zoology, Singhania University, Pacheri Bari, Jhunjhunu-333515 (Rajasthan), \\ India \\ *Corresponding author. Email: he15061991@ gmail.com
}

\section{Article Info}

https://doi.org/10.31018/

jans.v13i4.3182

Received: November 11, 2021

Revised: December 9, 2021

Accepted: December 12, 2021

\section{How to Cite}

Kumar, H. et al. (2021). Seasonal incidence and efficacy of botanical insecticides against Painted bug, Bagrada hilaris (Burmeister) (Hemiptera: Pentatomidae) in Indian mustard (Brassica juncea genotype RH 725). Journal of Applied and Natural Science, 13(4), 1518 - 1523. https://doi.org/10.31018/jans.v13i4.3182

\begin{abstract}
Bagrada hilaris (Burmeister) is a serious pest of Brassica crops in the North-Western region of India, inflicting crop yield losses. Therefore, the present study was conducted on seasonal incidence and management of $B$. hilaris in Brassica juncea genotype RH 725 at farmer's field, Kolana village, Aravalli Hills Region, Rewari, Haryana, India during Rabi, 2019-20 and 2020-21. This study laid out the trial in a randomized block design with three replications and six treatments viz., Neem Seed Kernel Extract (NSKE) @ 7\%, Nimbecidine @ 0.03\%, Neem oil @ 5\%, NSKE @ 5\%, Neem oil @ 7\% and control (unsprayed). Observations on the incidence of $B$. hilaris showed that it appeared from $5^{\text {th }}$ Standard Meteorological Week (SMW) $\left(0.34\right.$ bugs plant $\left.^{-1}\right)$ and attained peak during $10^{\text {th }} \mathrm{SMW}$ with 5.77 bugs plant $^{-1}$. The incidence of $B$. hilaris exhibited significant positive correlation with maximum $(r=0.852, p<0.05)$ and minimum $(r=0.900, p<0.05)$ temperature, rainfall $(r=0.763, p<0.05)$ and wind velocity $(r=0.959$, p <0.05). Spray of Neem oil @ 7\% (83.01\%) was the most effective in reducing the $B$. hilaris population over control followed by NSKE @ 7\% (81.48 \%), while NSKE @ 5\% (68.85\%) confirmed least effective. Seed yield in different treatments varied from $1440.5 \mathrm{~kg} \mathrm{ha}^{-1}$ (NSKE @ 5\%) to $1590 \mathrm{~kg} \mathrm{ha}^{-1}$ (Neem oil @ 7\%) against $1216 \mathrm{~kg} \mathrm{ha}^{-1}$ in control. The highest incremental costbenefit ratio was registered with NSKE @ 7\% (1: 7.70) followed by Nimbecidine @ 0.03\% (1: 7.41) and NSKE @ 5\% (1: 6.25). The present investigation signified that the study on the seasonal incidence of $B$. hilaris in relation to weather parameters could provide information for planning pest control and management strategies. The botanicals could be used as eco-friendly and economical substitutes for chemical insecticides at farmer's fields against this insect pest.
\end{abstract}

Keywords: Bagrada hilaris, Brassica, Insecticides, Management, Seasonal incidence, Weather parameter

\section{INTRODUCTION}

Rapeseed and mustard are the major Rabi oilseed crops that belong to the genus Brassica and family Cruciferae (Brassicaceae). It is one of India's economically significant agricultural produces. Rapeseed and mustard are placed third as important edible oilseed crops worldwide after soybean and palm oil. At the global level, it is mostly grown in tropical and subtropical regions (Panday et al., 1999; Balai et al., 2012; Choudhary et al., 2014). In India, rapeseed and mustard are cultivated on about 6.23 million ha, with the production of about 9.34 million tonnes. In Haryana, it is grown in 0.61 million ha area with a production of 1.25 million tonnes (Anonymous, 2019). The main oilseed Brassica species cultivated in India include 
Brassica juncea, $B$. napus, $B$. carinata, $B$. oleracea and $B$. nigra. Out of these, B. juncea (L.) Czern (Indian mustard) occupies a large area and makes an essential contribution in terms of oilseeds and edible oils production. It is mainly grown in the western to the central area of North India and in some non-traditional parts of southern India (Jat et al., 2019).

Ecological factors and insect pests are significant constraints that pose a severe hazard to Brassica from germination to harvest. It was attacked by about 50 insect species. The Bagrada hilaris (Burmeister) (Hemiptera: Pentatomidae), commonly referred to as the painted bug, is a major limiting factor in cruciferous crops in India. Its severe infestation at the pod formation and maturity stages cause losses of $30.1 \%$ in yield and $3.4 \%$ in oil content (Singh et al., 1980; Singh, 2008; Sharma and Singh, 2010). Weather parameters viz., temperature, humidity, rainfall, sunshine, wind speed and evaporation influence the incidence and thus vanishing of $B$. hilaris population (Divya et al., 2015; Singh et al., 2018). Continuous monitoring of this pest on Brassica crop is indispensable for devising a suitable pest management strategy.

Management of this insect pest in the Brassica crop is a basic need for obtaining a maximum seed yield of good quality. The use of chemicals to control insect pests leads to several problems viz., environment pollution, toxicity to pollinators and natural enemies, and adverse effects on human health (Singh, 2001). To overcome these problems, there is an immediate need to adopt environmentally safe and non-hazardous to human health approaches, like the use of botanical insecticides (Neem Seed Kernel Extract and Neemarin1500 ppm), for the management of $B$. hilaris (Kalasariya and Parmar, 2019; Vishvendra and Sachan, 2020). The earlier studies revealed that a number of chemical insecticides viz., Dimethoate $30 \mathrm{EC}$, Imidacloprid $17.8 \mathrm{SL}$, Thiamethoxam 25 WG, Malathion 50 EC, Chlorpyriphos 20 EC, Acetamiprid $20 \mathrm{SP}$ and Profenophos 50 EC were largely used and found effective to control this insect pest in India (Bawaskar et al., 2017; Ratnoo et al., 2018; Kalasariya and Parmar, 2019). Formulations made of Neem oil are used in organic farming, as it repels a wide variety of pests (Isman and Murray, 2006; Mishra et al., 1995). The present investigation aimed to study the seasonal incidence and efficacy of botanical insecticides to control the infestation of $B$. hilaris on Brassica crop.

\section{MATERIALS AND METHODS}

\section{Study area}

The field experiment was conducted at the farmer's field, Kolana village, Aravalli Hills Region, Rewari, Haryana, India during Rabi, 2019-20 and 2020-21. The geographical position is $28^{\circ} 12^{\prime} 24.7^{\prime \prime} \mathrm{N}$ latitude and $76^{\circ}$ $21^{\prime} 11.0$ "E longitude with an altitude of $296 \mathrm{~m}$. The soil of the trial site was sandy loam in texture.

\section{Selection of the genotype}

The B. juncea genotype RH 725 was taken from Regional Research Station, Bawal, Rewari of Chaudhary Charan Singh Haryana Agricultural University (CCS HAU), Hisar (Haryana).

\section{Experimental design for seasonal incidence}

Genotype RH 725 cultivar was sown on $20^{\text {th }}$ October of both the years (2019 and 2020) in the plot of $150 \mathrm{~m}^{2}$ area, with row to row and plant to plant distance of 30 and $10 \mathrm{~cm}$, respectively. The population of $B$. hilaris was recorded at the weekly interval, starting from the first appearance to harvest. Their number was counted from thirty randomly selected and tagged plants. The data on weather parameters viz., maximum and minimum temperature, morning and evening humidity, sunshine, rainfall, wind velocity and evaporation was collected from the meteorological observatory, CCS HAU, Regional Research Station, Bawal, Rewari (Haryana).

\section{Preparation of botanicals \\ Neem Seed Kernel Extract (NSKE)}

$1 \mathrm{~kg}$ of dried neem seed kernels crushed and soaked overnight in 10 litre water. Soaked material was filtered through muslin cloth and the volume of the filtrate was made to 10 litres. Dilute to $5 \%(50 \mathrm{ml}$ decanted solution in 1 litre of water) or $7 \%(70 \mathrm{ml}$ decanted solution in 1 litre of water) and $1 \%$ Teepol (10 ml litre ${ }^{-1}$ of water) was added at the time of spraying (Anonymous, 2008).

\section{Neem oil}

Neem seeds were picked from neem plants, and these seeds were dried and extracted in the oil expeller machine. Crude oil was filtered through muslin cloth and that oil was used as per the requirement of the experiment.

\section{Experimental design for evaluation of botanical insecticides}

A trial was laid out in the randomized block design (RBD) with three replications and six treatments, including control (unsprayed). The genotype RH 725 was sown with a spacing of $30 \times 10 \mathrm{~cm}$, in each plot size of $4.2 \times 3 \mathrm{~m}$. Five botanical insecticides were evaluated viz., Neem Seed Kernel Extract (NSKE) @ 7\%, Nimbecidine @ 0.03\%, Neem oil @ 5\%, NSKE @ 5\% and Neem oil @ 7\%. The spray was applied when the B. hilaris population reached the economic threshold level. The effect of insecticides was evaluated by counting nymphs and adults of $B$. hilaris from 10 randomly selected and tagged plants in each plot, a day prior (before spray) and $1^{\text {st }}, 3^{\text {rd }}, 7^{\text {th }}, 10^{\text {th }}$ and $15^{\text {th }}$ days after 
spray (DAS) of insecticides.

\section{Statistical analysis}

The data relating to correlation coefficients between weather parameters and $B$. hilaris incidence; and critical difference (CD) was statistically analysed using software OPSTAT (Sheoran et al., 1998). Per cent reduction in $B$. hilaris population over control was calculated by using the following formula.

Per cent reduction over control $=$ Population recorded in control (unsprayed) - Population recorded after spray / Population recorded in control (unsprayed)

The seed yield plot $^{-1}$ in different treatments was recorded and converted to kilogram hectare ${ }^{-1}\left(\mathrm{~kg} \mathrm{ha}^{-1}\right)$ after harvest. The Incremental Cost-Benefit Ratio (ICBR) was calculated by the prevailing market price of mustard seed, cost of insecticides and labour used with the following formula (Sharma et al., 2017).

ICBR = Additional profit over the control $\div$ Cost of treatment

\section{RESULTS AND DISCUSSION}

Effect of weather parameters on $B$. hilaris incidence Pooled data (Rabi, 2019-20 and 2020-21) regarding the effect of weather parameters on $B$. hilaris incidence shown in Fig. 1. The initial incidence of $B$. hilaris was observed from $5^{\text {th }}$ Standard Meteorological Week (SMW) (0.34 bugs plant $\left.{ }^{-1}\right)$, and after that increased during subsequent weeks with a peak during $10^{\text {th }} \mathrm{SMW}$ (5.77 bugs plant ${ }^{-1}$ ). The maximum and minimum temperature weekly during this peak was 27.9 and $12.05^{\circ}$ $\mathrm{C}$; morning and evening humidity were 87.5 and $41 \%$, respectively. The sunshine, rainfall, wind velocity and evaporation were $6.4 \mathrm{hrs}$., $25.65 \mathrm{~mm}, 4.05 \mathrm{~km} \mathrm{~h}^{-1}$ and $3.4 \mathrm{~mm}$, respectively. These observations are in contradiction with the findings of a field experiment on seasonal incidence of $B$. hilaris was conducted at Junagadh, Gujarat, India by Divya et al. (2015), who reported that peak population on $3^{\text {rd }}\left(7.05\right.$ bugs plant $\left.^{-1}\right)$ and $2^{\text {nd }}\left(6.95\right.$ bugs plant $\left.^{-1}\right)$ standard week when maximum temperature ranged from $28.8-11.1{ }^{\circ} \mathrm{C}$ and minimum temperature ranged from $27.3-12.2{ }^{\circ} \mathrm{C}$. The temperature and wind velocity influenced the incidence of $B$. hilaris more in comparison to other weather parameters. Correlation coefficients (Table 1 ) revealed a significant positive relationship with maximum ( $r=0.852$, $p=0.015)$ and minimum $(r=0.900, p=0.006)$ temperature, rainfall $(r=0.763, p=0.046)$ and wind velocity $(r=$ $0.959, p=0.001$ ), while non-significant positive with evening humidity $(r=0.160, p=0.732)$ and evaporation $(r=0.543, p=0.207)$; non-significant negative one with morning humidity $(r=-0.328, p=0.474)$ and sunshine hrs. $(r=-0.618, p=0.139)$. These results agree with those of Divya et al. (2015), who reported that morning relative humidity ( $r=-0.048$ and $r=-0.263$ ) had a nonsignificant negative association with $B$. hilaris incidence. Present findings are also corroborated with the results of the experiment conducted by Singh et al. (2018) at Kumarganj, Faizabad, India, and observed a significant positive correlation between the incidence of B. hilaris on Eruca sativa genotype T-27 and minimum temperature $(r=0.2785)$.

\section{Evaluation of botanical insecticides against $B$. hilaris}

The pooled data regarding the efficacy of insecticides given in Table 2 revealed that before spray, $B$. hilaris

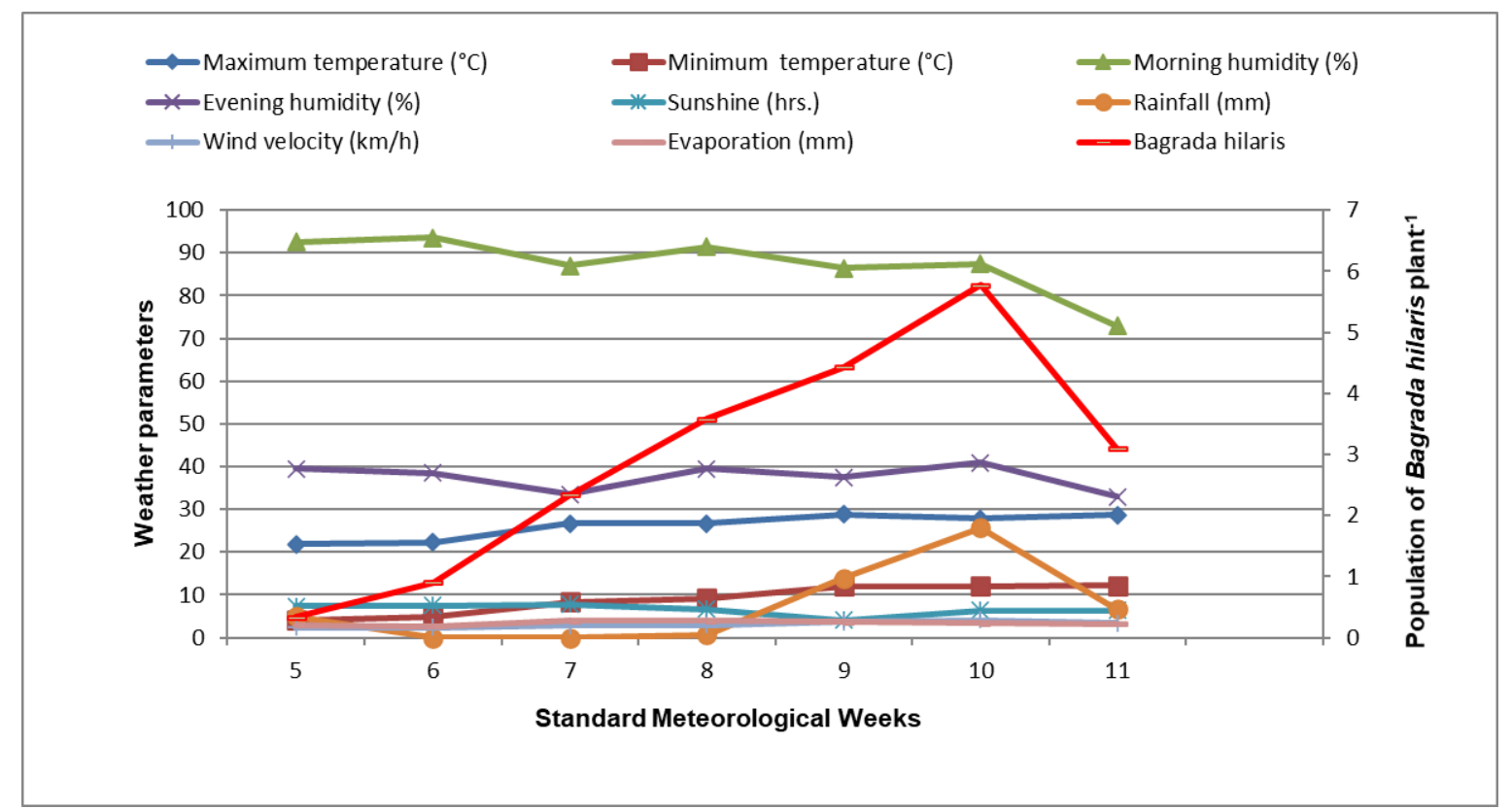

Fig. 1. Effect of weather parameters on population of B. hilaris (Pooled data of Rabi, 2019-20 and 2020-21) 
Table 1. Correlation coefficients between incidence of $B$. hilaris and weather parameters (Pooled data of Rabi, 2019-20 and 2020-21)

\begin{tabular}{lll}
\hline Weather parameters & Correlation coefficient $(\mathbf{r})$ & p- value \\
\hline Maximum temperature $\left({ }^{\circ} \mathrm{C}\right)$ & $0.852^{*}$ & 0.015 \\
Minimum temperature $\left({ }^{\circ} \mathrm{C}\right)$ & $0.900^{*}$ & 0.006 \\
Morning humidity $(\%)$ & -0.328 & 0.474 \\
Evening humidity $(\%)$ & 0.160 & 0.732 \\
Sunshine (hrs.) & -0.618 & 0.139 \\
Rainfall (mm) & $0.763^{*}$ & 0.046 \\
Wind velocity $\left(\mathrm{km} \mathrm{h}^{-1}\right)$ & $0.959^{*}$ & 0.001 \\
Evaporation $(\mathrm{mm})$ & 0.543 & 0.207 \\
\hline
\end{tabular}

*Significant at $\mathrm{P}=0.05$

Table 2. Efficacy of different treatments against B. hilaris (Pooled data of Rabi, 2019-20 and 2020-21)

\begin{tabular}{llllllll}
\hline \multirow{2}{*}{ Treatments } & \multicolumn{6}{c}{ Population of B. hilaris (nymph and adult) plant ${ }^{-1}$} & *\% Reduction \\
\cline { 2 - 6 } & Before spray & 1DAS & 3DAS & 7DAS & 10DAS & 15DAS & 15 DAS \\
\hline NSKE @ 7\% & $2.67(1.92)$ & $1.77(1.66)$ & $1.37(1.54)$ & $1.09(1.44)$ & $0.93(1.39)$ & $0.85(1.36)$ & 81.48 \\
Nimbecidine & $2.80(1.95)$ & $1.99(1.73)$ & $1.65(1.62)$ & $1.43(1.56)$ & $1.25(1.50)$ & $1.12(1.45)$ & 75.60 \\
@ 0.03\% & & & & & & & \\
Neem oil @ 5\% & $2.84(1.96)$ & $2.24(1.80)$ & $1.93(1.71)$ & $1.69(1.64)$ & $1.49(1.58)$ & $1.35(1.53)$ & 70.59 \\
NSKE @ 5\% & $2.80(1.95)$ & $2.32(1.82)$ & $1.99(1.73)$ & $1.73(1.65)$ & $1.57(1.60)$ & $1.43(1.56)$ & 68.85 \\
Neem oil @ 7\% & $2.58(1.89)$ & $1.67(1.63)$ & $1.25(1.50)$ & $1.03(1.43)$ & $0.85(1.36)$ & $0.78(1.33)$ & 83.01 \\
Control & $2.38(1.84)$ & $2.82(1.95)$ & $3.27(2.07)$ & $3.70(2.17)$ & $4.24(2.29)$ & $4.59(2.36)$ & \\
CD at 5\% & & 0.09 & 0.12 & 0.15 & 0.14 & 0.16 & \\
SE $(\mathrm{m})$ & 0.04 & 0.03 & 0.04 & 0.05 & 0.04 & 0.05 & \\
\hline
\end{tabular}

*Per cent reduction in B. hilaris population over control 15 DAS; Figures in parentheses are square root transformations; DAS: Day after spray

population ranged between 2.38 to 2.84 bugs plant $^{-1}$. All the botanical insecticides significantly reduced the $B$. hilaris population after one, three, seven, ten and fifteen days after spray (DAS). At $1^{\text {st }}$ DAS, Neem oil @ $7 \%$ spray was found most effective (1.67 bugs plant $\left.{ }^{-1}\right)$ against $\left(2.82\right.$ bugs plant $\left.^{-1}\right)$ control and it was statistically at par with NSKE $@ 7 \%\left(1.77\right.$ bugs plant $\left.^{-1}\right)$. The next most effective insecticide was Nimbecidine @ 0.03\% (1.99 bugs plant ${ }^{-1}$ ) spray, which was statistically at par with Neem oil @ 5\% (2.24 bugs plant $\left.{ }^{-1}\right)$. Insecticide, NSKE @ $5 \%$ was least effective, having a B. hilaris population of 2.32 bugs plant $^{-1}$.

Data recorded on the $3^{\text {rd }}, 7^{\text {th }}, 10^{\text {th }}$ and $15^{\text {th }}$ DAS also exhibited a similar trend of the efficacy of different botanical insecticides. The $B$. hilaris population ranged from 1.25 to 1.99 bugs plant $^{-1}$ at $3^{\text {rd }}$ DAS, 1.03 to 1.73 bugs plant ${ }^{-1}$ at $7^{\text {th }}$ DAS, 0.85 to 1.57 bugs plant $^{-1}$ at $10^{\text {th }}$ DAS and 0.78 to 1.43 bugs plant $^{-1}$ at $15^{\text {th }}$ DAS.

The pooled data (Table 2) on per cent reduction in $B$. hilaris population over control at $15^{\text {th }}$ DAS revealed that spray of Neem oil @ 7\% (83.01\%) was found to be the best over the rest of the botanical insecticides. It was followed by NSKE @ 7\% (81.48 \%) and Nimbecidine @ $0.03 \%$ (75.60 \%). Minimum reduction in B. hilaris population was found with Neem oil @ 5\% (70.59\%) and NSKE @ 5\% (68.85\%).These results are in accordance with the findings of the experiment carried out at Hisar, Haryana, India by Bawaskar et al. (2017), who concluded that Nimbecidine 1500 ppm (45.64\%) was effective in reducing the $B$. hilaris population on the Brassica juncea genotype RH 30 . Similarly, these observations also validate with those of Vishvendra and Sachan (2020), who conducted a field experiment at Meerut, Uttar Pradesh, India, and found NSKE (40 and $43.71 \%)$ were effective against $B$. hilaris on $B$. juncea genotype Pusa bold.

\section{Impact of $B$. hilaris management on seed yield of Brassica}

Data of seed yield given in Table 3 revealed that spray of insecticides was effective to protect the crop from the infestation of B. hilaris. The spray of Neem oil @ 7\% 
Kumar, H. et al. / J. Appl. \& Nat. Sci. 13(4), 1518 - 1523 (2021)

\begin{tabular}{|c|c|c|c|c|c|c|c|}
\hline Treatments & $\begin{array}{l}\text { Cost of in- } \\
\text { secticides } \\
\left(\text { Rs. ha } \text { ha }^{-1}\right.\end{array}$ & $\begin{array}{l}\text { Labour } \\
\text { charge } \\
\left(\text { Rs. ha }{ }^{-1}\right)\end{array}$ & $\begin{array}{l}\text { Total } \\
\text { expenditure } \\
\text { (Labour + } \\
\text { insecticide) } \\
\left(\text { Rs. } \text { ha }^{-1}\right)\end{array}$ & $\begin{array}{l}\text { Seed yield } \\
\left(\mathrm{kg} \mathrm{ha}^{-1}\right)\end{array}$ & $\begin{array}{l}\text { Gross } \\
\text { income } \\
\left(\text { Rs. ha }{ }^{-1}\right)\end{array}$ & $\begin{array}{l}\text { Net return } \\
\text { over } \\
\text { control } \\
\left(\text { Rs. } \text { ha }^{-1}\right)\end{array}$ & ICBR \\
\hline \multirow{2}{*}{$\begin{array}{l}\text { NSKE @ 7\% } \\
\text { Nimbecidine @ } \\
0.03 \%\end{array}$} & 1260 & 450 & 1710 & 1567 & 58763 & 13163 & $1: 7.70$ \\
\hline & 1140 & 450 & 1590 & 1529.5 & 57375 & 11775 & 1: 7.41 \\
\hline Neem oil @ 5\% & 1550 & 450 & 2000 & 1449.5 & 54375 & 8775 & 1: 4.39 \\
\hline NSKE @ 5\% & 900 & 450 & 1350 & 1440.5 & 54038 & 8438 & $1: 6.25$ \\
\hline Neem oil @ 7\% & 2170 & 450 & 2620 & 1590 & 59625 & 14025 & $1: 5.35$ \\
\hline Control & & & & 1216 & 45600 & & \\
\hline
\end{tabular}

ICBR: Incremental Cost Benefit Ratio; *Mustard seed rate @ 3750 Rs. qt ${ }^{-1}$

gave the maximum seed yield (1590 kg ha $\left.{ }^{-1}\right)$, which was found superior as a comparison to the rest of the insecticides, followed by NSKE @ 7\% (1567 kg ha $\left.{ }^{-1}\right)$ and Nimbecidine @ 0.03\% (1529.5 kg ha $\left.{ }^{-1}\right)$. The lowest seed yield (1440.5 $\mathrm{kg} \mathrm{ha}^{-1}$ ) was registered with NSKE @ 5\% and Neem oil @ 5\% (1449.5 kg ha $\left.{ }^{-1}\right)$ whereas, the seed yield recorded in control was only $1216 \mathrm{~kg} \mathrm{ha}^{-1}$.

\section{Economics and Incremental cost-benefit ratio (ICBR)}

Table 3, in respect of economics of botanical insecticides, revealed that the maximum gross income and net return over control were obtained with the use of Neem oil @ 7\% (Rs. 59625 and Rs. 14025) followed by NSKE @ 7\% (Rs. 58763 and Rs. 13163). In contrast, the minimum found with NSKE @ 5\% (Rs. 54038 and Rs. 8438). Based on ICBR of different insecticides, NSKE @ 7\% was the most economic insecticide because it gave the maximum cost profit (1: 7.70) compared with the remaining insecticides. The next profitable insecticides were Nimbecidine @ 0.03\% (1: 7.41) and NSKE @ 5\% (1: 6.25). The lowest ICBR was obtained from Neem oil @ 5\% (1: 4.39). There appears to be no report regarding the efficacy of botanical insecticides against $B$. hilaris on $B$. juncea genotype $\mathrm{RH} 725$.

\section{Conclusion}

The present study deduced that weather parameters greatly impacted the occurrence, multiplication, and disappearance of $B$. hilaris population on Brassica juncea genotype RH 725. Botanical insecticides like Neem oil @ 7\% (83.01\%) and NSKE @ 7\% (81.48\%) were effective in controlling the $B$. hilaris population and are safer, eco-friendly, and economically viable. Therefore, considering human health and environmental safety, it could be recommended that farmers can use botanical insecticides as an alternative to chemical insecticides to protect the Brassica crops against infestation of $B$. hilaris.

\section{ACKNOWLEDGEMENTS}

The authors thank the late Dr. Satyapal Yadav, Assistant Scientist, Department of Entomology, CCS Haryana Agricultural University, Regional Research Station, Bawal, Rewari, Haryana for their help and valuable suggestions.

\section{Conflict of interest}

The authors declare that they have no conflict of interest.

\section{REFERENCES}

1. Anonymous (2008). Proceedings of AICRP Group meeting on rapeseed-mustard, Bhubneswar (Orissa), Aug. 7-9.

2. Anonymous (2019). Agricultural statistics at a glance. Government of India, Ministry of Agriculture, Department of Agriculture \& Cooperation, Directorate of Economics \& Statistics, Krishi Bhawan, New Delhi.

3. Balai, C. M., Meena, R. P., Meena, B. L. \& Bairwa, R.K. (2012). Impact of front line demonstration on rapeseedmustard yield improvement. Journal of Extension Education, 12(2), 113-116.

4. Bawaskar, D. M., Yadav, S., Singh, S. P. \& Nadaf, A. (2017). Efficacy and economics of seed treatment and foliar spray with insecticides against Bagrada hilaris (Burmeister) in Indian mustard (Brassica juncea L.). Journal of Oilseed Brassica, 8 (1), 80-88.

5. Choudhary, M., Sangha, J. K. \& Grover, K. (2014). Conventional and non-conventional edible oils: An Indian perspective. Journal of the American Oil Chemists' Society, 91(2), 179-206.

6. Divya, C., Kalasariya, R. L. \& Kanara, H. G. (2015). Seasonal incidence of mustard painted bug, Bagrada hilaris (Burmeister) and their correlation with abiotic factors on mustard. Journal of Insect Science, 28 (1), 92-95.

7. Isman \& Murray, B. (2006). Botanical Insecticides, Deterrents, and Repellents in Modern Agriculture and an Increasingly Regulated World. Annual Review of Entomology, 51, 45-66. doi:10.1146/annurev.ento.51.11010 4.151146 . 
8. Jat, R. S., Singh, V. V., Sharma, P. \& Rai, P. K. (2019). Oilseed Brassica in India: Demand, supply, policy perspective and future potential. OCL, 26, 8. doi:10.1051/ ocl/2019005

9. Kalasariya, R. L. \& Parmar, K. D. (2019). Management of painted bug, Bagrada hilaris (Burmeister) in mustard with different spray schedules. Journal of Entomology and Zoology Studies, 7(3), 1157-1163.

10. Mishra, A. K., Singh, N. \& Sharma, V. P. (1995). Use of neem oil as a mosquito repellent in tribal villages of mandla district, madhya pradesh. Indian Journal of Malariology, 32 (3), 99-103.

11. Panday, I. D., Singh, B., \& Sachan, J. N. (1999). Brassica hybrid research in India: status and prospects. Proceedings of the tenth international rapeseed congress. Canberra, Australiam.

12. Ratnoo, S. D., Pandey, S. \& Joshi, N. (2018). Efficacy of insecticides against painted bug Bagrada cruciferarum kirkaldy in mustard. Journal of Entomology and Zoology Studies, 6(4), 121-122.

13. Sharma, D., Yadav, S. P. \& Yadav, S. (2017). Biointensive integrated management of Lipaphis erysimi Kalt. (Homoptera: Aphididae) in Brassica spp. Journal of Applied and Natural Science, 9 (4), 2132 -2136.

14. Sharma, P. \& Singh, Y. P. (2010). Directorate of Rapeseed- Mustard Research, Indian Council of Agriculture
Research, Sewar, 321303, Bharatpur (Rajasthan). Annals National Language Journal, 1, 47-51.

15. Sheoran, O. P., Tonk, D. S., Kaushik, L. S., Hasija, R. C. \& Pannu, R. S. (1998). Statistical Software Package for Agricultural Research Workers (pp 139- 143). Recent Advances in information theory, Statistics \& Computer Applications by D.S. Hooda and R.C. Hasija Department of Mathematics Statistics, CCS HAU, Hisar.

16. Singh, H. Y., Gupta, D. S., Yadava, T. P. \& Dhawan, K. (1980). Post harvest losses caused by painted bug (Bagrada cruciferarum Kirk.) to mustard. HAU Journal of Research, 10, 407-409.

17. Singh, P. K. (2001). Control of mustard aphid, Lipaphis erysimi (Kalt.) (Homoptera: Aphididae) with minimum insecticide use. Journal of Aphidology, 15,139 -142.

18. Singh, S. P. (2008). Insect pest management in oilseed crops. Indian Farming, 58, 29-33.

19. Singh, S., Kumar, S., Singh, J., Dohare, A. P. S., Kumar, P. \& Lal, M. N. (2018). Population Dynamics of Painted Bug (Bagrada hilaris), in Different Varieties of Brassica Oil Seed Crops. International Journal of Current Microbiology and Applied Sciences, 7, 3682-3685.

20. Vishvendra \& Sachan, S. K. (2020). Evaluate the efficacy of some novel insecticides against Bagrada hilaris, (Burm) in Brassica sp. under natural condition in west UP, India. International Journal of Fauna and Biological Studies, 7 (5), 15-16. 